\title{
The Equity Effects of Property Tax Caps: Evidence from Florida
}

Mary Beal

Department of Economics \& Geography, University of North Florida, Jacksonville, FL, USA

Mary O. Borg

Department of Political Science \& Public Administration, University of North Florida, Jacksonville, FL, USA

Doi: 10.2478/ajis-2018-0039

\author{
Harriet Stranahan \\ Department of Economics \& Geography, \\ University of North Florida, Jacksonville, FL, USA
}

\begin{abstract}
Over the last decade Florida property owners have saved billions of dollars in taxes due to a 1995 assessment cap initiative which reduced homeowner's tax burdens. Florida is not alone in passing assessment caps, 20 other states have passed similar property tax reductions. Proponents of Florida's initiative said the measure would protect the elderly, many of whom live on fixed incomes in retirement, from property tax inflation. This research examines the vertical and horizontal equity effects of assessment caps. Using data from a large MSA in Florida, the results provide new evidence on which groups of homeowners are more likely to benefit from these types of initiatives.
\end{abstract}

Keywords: Property Tax Caps, Horizontal \& Vertical Inequity, Economic Incidence, Heckman Selection, Suits Index

\section{Introduction}

Property tax assessment reform initiatives have been a continuing part of American politics since 1978, when California voters passed Proposition 13. California's Proposition 13 limited the ad valorem taxes on all property to a maximum of one percent of their 1975 assessment. This led to a surge of states placing similar tax limitation initiatives (assessment caps) on their ballots (University of Florida Shimberg Center for Housing Studies, 2007). Massachusetts' Proposition $21 / 2$ and Florida's "Save Our Homes" amendment were two major initiatives that followed in 1980 and 1992 , respectively. Over 20 states $^{1}$ currently have implemented some type of property tax assessment limit (Haverman \& Sexton, 2008). Property tax limitations are and continue to be an important issue and seem to be most appealing when citizens feel overtaxed and underserved.

Assessment caps can significantly affect homeowners' tax burdens. Florida has had a tax assessment limit in place since 1995 and in 2006 alone, the property tax cap reduced the taxable values in the state by over $\$ 400$ billion, which amounts to a total tax benefit of approximately $\$ 7.4$ billion (Florida DOR, 2007) ${ }^{2}$. Although policymakers recognize the size and growing importance of assessment caps initiatives, very little is known about who is actually receiving these tax breaks and whether they are equitably distributed across different demographic and socioeconomic groups $^{3}$.

\footnotetext{
${ }^{1}$ District of Columbia is included in this count.

${ }^{2}$ This calculation is based on the average Florida millage rate in 2006 which was 18.47 mills.

${ }^{3}$ Indeed, most research has focused on the vertical equity implications of the property taxes (Plummer, 2003).
} 
Research on tax equity and fairness most often focuses on vertical equity, which measures how tax rates differ across income groups, and whether the taxes are progressive, regressive, or proportional. In order to present a more complete picture, our study examines both the vertical and horizontal equity effects of assessment caps. Richard Musgrave's definition of horizontal equity states that "people in equal positions should be treated equally" (1959, p. 160). We interpret this to mean that households with similar characteristics should bear similar tax burdens. All else equal, when households in different age, ethnicity or socioeconomic (SES) classes pay significantly different tax amounts, this violates the principle of horizontal equity. For example, would it be fair if the lion's share of a tax increase was paid by minority, less-educated, senior citizens? For good reason, horizontal equity has been used as one important tenet of equity, and in this study, it provides a framework for voters and policymakers to better judge the efficacy and fairness of tax policy proposals. We believe there should be no distinction between a tax or a tax savings in terms of equity: both should face the same equity principles. Stiglitz (2001) analyzes tax breaks by calling them tax expenditures. He emphasizes that anytime Congress or voters pass a tax preference, it is equivalent to spending tax dollars (it has exactly the same effect on the government's budget as an equal amount of new spending).

Using Musgrave's original definition of horizontal equity, our study provides new evidence about whether the billions in property tax savings due to assessment cap limitations in Florida are equitably distributed over different socioeconomic or demographic groups. Policymakers and voters debating assessment cap tax policy will benefit from more information about the real world consequences of assessment caps.

The paper is structured as follows. The literature review discusses two veins of research related to our topic. The first is the economics literature focusing on property tax incidence, and the second is the real estate literature focusing on the equity implications of assessment caps. We continue with a discussion of the methodology and data used in our analysis. Finally, we present our model results followed by a discussion of our conclusions about the equity consequence of assessment tax limitations.

\section{Literature on Property Tax Vertical and Horizontal Equity}

Vertical equity has been the primary focus of numerous studies in the economics literature examining tax incidence. Traditionally, these studies compute a taxpayer's average tax rate (the proportion of income that goes to pay taxes) and then estimate whether average tax rates differ as income rises. The average tax rate falls as income increases for a regressive tax, stays constant for a proportional tax, and increases for a progressive tax (Stiglitz, 2000). In studies of property tax incidence, individual homeowner's income is frequently not available and so one of two methods is generally employed to calculate the average tax rate. One method uses the market value of the home as a surrogate measure of the homeowner's 'permanent' income. The second uses aggregated current income within a given area, a county, for example. The data obtained from one or both of these methods is then used to compute a Suits index which is designed to provide information about whether the tax is regressive, proportional, or progressive.

A Suits Index uses a Lorenz curve to compare the cumulative distribution of the tax burden to the cumulative distribution of income. The index takes on values from -1 (perfectly regressive) to +1 (perfectly progressive) with a value of zero indicating a perfectly proportional tax. The index is a broad, aggregate measure that compares the proportion of property tax paid by each decile $(10 \%)$ of households to the proportion of income earned by each decile.

Numerous studies (Suits, 1977; Phares, 1980; Metcalf, 1994; Plummer, 2003) have used the Suits index to measure the vertical equity of property taxes. There has been some debate in the literature about whether current or permanent income is a preferred measure for use in calculating Suits indexes (Metcalf, 1994). However from a practical standpoint, empirical results suggest that the use of permanent versus current income makes little difference in the size of estimated Suits indexes. Three studies that use current income (Suits, 1977; Phares, 1980; Metcalf, 1994) show that property taxes have no clear pattern of progressivity or regressivity. The Suits index ranges from +0.23 (slightly progressive) to -0.23 (slightly regressive) in these studies. Two articles (Metcalf, 
1994 and Plummer, 2003) that use permanent income (proxied by current home value), also show wide variation with Suits indexes that range from -0.11 to +0.26 . Overall, these studies provide no clear consensus about whether property taxes are progressive, proportional or regressive.

In the real estate literature, studies on vertical equity focus on whether average tax rates vary across the tax base (property values) due to under or overvaluation during assessment. These studies measure differences in the assessment to sales price ratio across neighborhoods. Several studies (McGreal et al., 2007; Allen, 2003; Birch, Sunderman and Smith, 2004; Smith, 2000) find that less expensive neighborhoods have higher assessment to sales price ratios (A/S). This implies that property taxes are regressive. There is not a consensus on this point in the literature, however. Other studies (Cornia and Slade, 2005; Goolsby, 1997; Sirmans et al., 1995) find little evidence of biased assessments or vertical inequities using similar methods. In fact, Cornia and Slade (2006) suggest that vertical equity may be improving over time because the International Association of Assessing Officers has introduced changes in industry standards that provide greater uniformity in assessment practices. Fewer studies focus on the horizontal equity of property taxes, and most of these use A/S ratios to measure inequity. Harris (2004) finds that black and Latino neighborhoods pay higher property taxes and have higher A/S ratios compared to white neighborhoods. In an AARP sponsored survey, Baer (2005) found that seniors (65+ years old) pay proportionately more of their current income in property taxes than younger homeowners.

Other studies of horizontal equity have measured the variation in A/S ratios across similar homes. A given jurisdiction is more horizontally equitable when homes are uniformly assessed, i. e. there is lower variation in A/S ratios. To measure variation, most research uses the coefficient of variation or the variation of $\mathrm{A} / \mathrm{S}$ ratios around the neighborhood mean. Using this methodology on a sample of single family homes in south Florida, Allen and Dare (2002) find higher variation in A/S ratios (i.e., more horizontal inequity) for larger homes, older homes and homes in neighborhoods with a higher percentage of minorities. However, there is less variation (and so less inequity) in the assessment ratios in high income neighborhoods and neighborhoods with more market activity. However, Cornia and Slade's (2006) more recent study finds that the horizontal inequity in property assessments may be diminishing due to more uniform assessment standards.

The popularity of assessment cap referendums has raised concerns that these initiatives tend to shift the tax burden to the poor (Moore, 2009). Focusing just on assessment caps, several studies use raw data to calculate household level tax savings. There is an emerging consensus in the literature (IAAO, 2008; Anderson, 2006; Bowman, 2006; Dye et al., 2006) that assessment caps are likely to shift the tax burden away from individuals who own rapidly appreciating homes to homeowners whose property has not appreciated as much. This latter group tends to own less expensive homes and to have owned their homes for fewer years.

Moore (2009) used a slightly different methodology to measure assessment cap equity. He calculated the variability of the A/S ratio for homes that have assessment caps and for homes that have no assessment limits. He found that assessment caps in Florida have significantly increased both the vertical and horizontal inequities in the tax structure. A study by Allen and Dare (2009) found similar inequities. Using a sample of 17 million homeowners in Florida, the authors regressed the market value shielded from taxation due to Save Our Homes' as a percent of home value against the house's value and found that assessment cap benefits rise with house value. Not surprisingly, this effect is magnified over time as households with longer tenure accrue larger and larger tax benefits. This means that assessment caps are regressive (i.e., the assessment cap provides smaller proportionate tax savings to those whose homes are less valuable) and so they make the property tax less progressive.

Using a methodology similar to the one employed by Allen and Dare (2009), we estimate a regression equation using the market value shielded from taxation as a percent of income as the dependent variable. There is some debate among economists about whether property tax incidence should be measured relative to permanent or current income. Some argue that property tax incidence should be measured using permanent income because housing consumption decisions (and their accompanying tax burdens) are made over a long- term time horizon. In essence, a household's tax burden should be defined relative to their housing wealth not their ability to pay out of current income. Another argument for using permanent income is that using current income in a 
cross sectional study may bias the results so that property taxes appear more regressive and property tax breaks appear more progressive than they actually are in reality (see Metcalf, 1994).

On the other hand, proponents of assessment cap tax relief argue that rising property taxes are an onerous burden precisely because they must be paid out of current income, i.e., the opportunity cost of paying higher property taxes is current consumption not house value (Englund, 2003). Using this rationale, current income is a more relevant framework for evaluating property tax breaks. Although we find the arguments for using current income more compelling, we believe that both arguments have merit. Therefore, we estimate two separate regressions, one that uses market value shielded from taxation as a percent of permanent income as the dependent variable (similar to Allen and Dare, 2009) and a second that uses market value shielded from taxation as a percent of current income as the dependent variable. Results from these regressions will show whether high or low income households enjoy a disproportionate share of the tax savings from assessment cap initiatives.

In addition, we add another analytical dimension to our discussion of vertical equity. Following the methodologies employed in the economics literature, we begin the analysis of vertical equity by reporting a Suits index. The Suits index does not account for household demographic factors but provides a well accepted aggregate measure indicating whether assessment cap benefits are proportionately higher for some income groups than for others.

Furthermore, our study extends previous research by including a variety of socioeconomic and demographic independent variables to our regression analysis in an effort to shed light on the horizontal equity implications of assessment caps. Thus, we are able to provide new information about which demographic and socioeconomic groups are likely to garner the bulk of the tax benefits received from assessment caps.

\section{Data \& Methodology}

In 1992, Florida voters approved the Save Our Homes (SOH) amendment. The amendment was placed on the general election ballot following a campaign led by Save Our Homes, Inc., a Ft. Meyers-based group, that collected over 400,000 voter signatures on a petition (University of Florida Shimberg Center, 2007) $)^{5}$. The group argued that the property tax limitation would protect elderly homeowners who could not keep up with property tax increases due to the rapidly rising home value assessments in some locations. The assessment growth limitation first affected property valuation on the 1995 tax roll and applied only to owner-occupied (homesteaded) properties. The SOH provision limits the annual growth in assessed value of the property to $3 \%$ or the percentage change in the Consumer Price Index, whichever is lower. Additionally, the assessed value of the property is never able to exceed the just value. The $\mathrm{SOH}$ amendment protects a homesteaded property's taxable value from increasing in years with substantial increases in just or market value. This property tax limitation provides an excellent opportunity to examine equity issues.

\footnotetext{
${ }^{4}$ Young families tend to have less current income but tend to consume more housing to meet the needs of a growing family and as a result pay more in property taxes. Later in the lifecycle, older households reaching the peak of their earning potential are likely to downsize into smaller homes resulting in a smaller tax bill. A cross sectional analysis with current income in the regression may lead to higher income households paying proportionately less property tax out of 'current' income; the result is a regressive tax. Using this same rationale for an assessment cap, all else equal, a younger, lower income household may earn a larger tax break because their larger home appreciates more rapidly than the smaller home of a 'mature' high income household. In the context of housing consumption over the lifecycle, all else equal, using current income (instead of permanent income) should result in the assessment cap benefit being more progressive, i.e, lower income young households will earn more tax benefit than higher income older households.

${ }^{5}$ Florida Save Our Homes Amendment was passed by a relatively close vote of 53.6 to 46.4 percent, with 34 counties supporting the amendment and 33 opposing it. Strong support was found in southern counties and counties on the eastern seaboard. Major metropolitan areas and counties with above average household incomes also supported the amendment (University of Florida Shimberg Center, 2007).
} 
The data set used in this study was obtained from the Florida Department of Revenue (DOR). The DOR data set is a cross-sectional database that includes a variety of property- and ownerspecific characteristics such as current market value, assessed property value, dates of sales for every parcel in Duval County Florida. Property records for all residential owner-occupied singlefamily detached residences located in the Jacksonville Metropolitan Statistical Area (Clay, Duval, Nassau, St. Johns counties) in the year 2013 were selected for the analysis $(233,787$ total observations).

One major limitation of the DOR data set (similar to other property tax data) is the lack of information on the taxpayer's current income. Therefore, for this analysis all property level data is aggregated to the census block group level. The block group is the smallest geographic unit of the U.S. Census. In cities, the block group is bounded by streets, roads, or creeks and is usually no bigger than one city block. However, in more rural areas, the block group is usually a larger area. Because our sample is restricted to owner-occupied detached residential units (as opposed to condominiums or rental units), the block group data provide a relatively accurate approximation of the homeowner's characteristics. Data from these small homogenous block groups are routinely used as independent variables to estimate household characteristics by government and businesses undertaking market or policy analysis (U.S. Census Bureau, 2002). The 233,787 owneroccupied single family homes in this study were aggregated into 389 block groups. Then, each block group was linked with the economic and demographic block group level data available from the U.S. Census American Community Survey (ACS) 5 Year Estimates (2009-2015). Therefore, the median income in the census block group is used as a proxy for the homeowner's current income. In addition to median income, the ACS includes a variety of other demographic characteristics such as age, ethnicity, and educational attainment of household residents.

The descriptive statistics for the variables used in this analysis are shown in Table 1 . The 2013 average market/just value of owner-occupied single family homes per block group in the sample is $\$ 159,843$, which is higher than the mean assessed value of $\$ 146,278$. This implies an average difference in market value and assessed value (amount shielded from taxation due to Save Our Homes) of a little over $\$ 13,000$ per household in $2013^{6}$. For the jurisdictions in our sample, the average millage rate is $17.79 \%$, which implies that for each $\$ 1,000$ of taxable home value, the homeowner pays about $\$ 17.79$. As a result, the average tax savings or benefit due to Florida tax assessment limitation is $\$ 241$ per household, on average. The average block group has $75 \%$ of the homeowners that are Caucasian, 22\% that have children under age 18 living in the home; and nearly $89 \%$ of the population with at least a high school education. The average median income per block group is $\$ 58,813$. The average market value shielded from taxation as a percentage of permanent income is $7 \%$ and the average market value shielded from taxation as a percentage of current income is almost $24 \%$ for the block groups in the sample.

To understand how tax benefits from assessment caps are distributed across homeowners, we employ two methodologies. First, we estimate a Suits Index which is a summary measure of the distribution of a tax that is used to evaluate the progressivity of a tax. The Suits Index is measured using both permanent income (block group market value) and current income (block group median income). OLS regression analysis is also employed (at the block group level) to estimate the impact of different socioeconomic characteristics on the market value shielded from taxation due to Save Our Home as a percentage of income (both permanent and current).

\section{Vertical Equity Results}

Looking first at vertical equity, we use two different methodologies to explore the vertical equity implications of assessment caps. Both the Suits index and the regression results provide new evidence about whether assessment caps are higher for some income groups than others.

Tables 2 and 3 show the Suits index calculations along with aggregated income and market

\footnotetext{
${ }^{6}$ This is the average value of the reduction in the assessed value of the property, not the average tax savings.
} 
value shielded from taxation due to Save Our Homes for different deciles of block groups within the Jacksonville MSA. The results in Table 2 were calculated using permanent income (market/just value) and those in Table 3 were calculated using current income as proxied by the census block group's median income. We find surprisingly similar results. Both calculations show that the assessment cap tax benefits are just slightly progressive (Suits $\approx-0.08$ ). The lowest decile gets slightly more proportional tax benefits than its income share, and the highest decile gets slightly less proportional tax benefits than its income share.

Recognizing that the Suits index is a well established measure of vertical equity, it does, however, suffer from two shortcomings. One is that it is an aggregated measure; it really only gives us information about groups of homeowners, not individual households. We know the proportion of tax benefits received by the ten percent of homeowners with the lowest home values (Table 2) or the lowest current incomes (Table 3), but we know nothing about the individual households who make up that ten percent. The second problem is that the Suits index does not account for other factors that affect tax benefit; it accounts only for income. Using only income potentially ignores other important predictors of tax benefits and subjects the analysis to the risk of omitted variable bias. Regression analysis is a useful methodology that addresses this concern and provides another way of examining the vertical and horizontal equity aspects of assessment cap initiatives.

The regression results in Table 5 show the relationship between tax benefit incidence (tax savings as a percent of income) and income using both permanent income (Column 1) and current income (Column 2). After accounting for the holding period (years of tenure in the home), education, ethnicity, age and presence of children as other independent variables, we find that income is negatively related to tax benefit incidence. Low income households (as measured by either current or permanent income) get proportionately more tax savings than high income households; thus, assessment caps are progressive. This result is consistent with our results using the Suits index, but contrary to the results reported in Dare and Allen (2009). Recall that Dare and Allen (2009) found a positive relationship between income and tax benefit as a percent of permanent income. The difference between our results and theirs may be due to the fact that Dare and Allen (2009) included only permanent income in a regression that may have omitted other important predictors.

\section{Horizontal Equity Results}

Horizontal equity examines whether there are significant differences in the property tax savings of different groups of homeowners based on their ethnicities, education levels, ages of household heads, family compositions or holding period for the home. Holding income constant, if there are differences in the homeowner's tax savings based on these characteristics, then the principle of horizontal equity has been violated. The results of our regression analysis, shown in Table 4, will allow us to determine whether the $\mathrm{SOH}$ amendment violates this principle.

The results suggest that the billions in tax savings resulting from $\mathrm{SOH}$ are not uniformly distributed across demographic groups. One of those demographic groups is delineated by educational attainment. In most cases, households with higher levels of education receive higher tax benefits as a percent of current income than those with the lowest level of educational attainment. More highly educated homeowners probably live in higher priced and more quickly appreciating properties that accumulate more tax savings. The opposite would be true for households with the lowest levels of education. However, the negative coefficient on the variable denoting college graduates in the permanent income regression conflicts with this story. This coefficient suggests that college graduates get fewer benefits as a percent of house value than households with the least educational attainment. We find in Table 4 that college graduates were more likely to sell their homes in 2007. If they are more mobile, then this could explain the fact that their benefits are lower relative to their home's value since they are more likely to have recently purchased a home.

Our results also suggest that the $\mathrm{SOH}$ tax savings are not distributed equally across ethnic groups. We find that blacks receive proportionately less tax relief than do whites, and this is true whether we measure their savings as a proportion of permanent or current income. Statistically 
speaking, research suggests that minorities tend to live in lower priced neighborhoods with lower levels of home price appreciation, which could explain why our study finds that blacks suffer an unequal distribution of property tax savings.

Results in Table 4 show that Hispanics and other ethnic groups were as mobile as whites in 2007, and the results in Table 5, Column 1 indicate that the tax benefits of both groups relative to their permanent income (the home's value) is not significantly different from that of whites. However, Column 2 of Table 5 shows that Hispanics get about 1.6 percent more tax savings relative to their current incomes than whites, while the other ethnic group gets 1.5 percent less tax savings relative to their current incomes than whites. It is hard to explain why these differences exist, but our study suggests that one real world consequence of the assessment caps is that Hispanic and other ethnic group homeowners get significantly different $\mathrm{SOH}$ tax benefits as a percent of their current incomes than white homeowners. Furthermore, the difference between the tax savings received by Hispanic and other ethnic group homeowners is especially significant, amounting to over $3 \%$ of their current incomes.

Family composition is the basis of another demographic group that receives different amounts of tax savings from assessment caps. Results show that neighborhoods that have more children living at home receive higher tax savings as a percent of current income than neighborhoods with fewer children. Young families may have low current income, but with easy credit (as was typical in 2007), they could afford more expensive homes. Tax assessment limits reward these consumption preferences resulting in young families getting more tax savings as a percent of current income. However, this is not the case with respect to permanent income. The results suggest that households with children get about the same amount of tax savings as a percent of permanent income (home value) as others.

Over the household lifecycle, seniors tend to downsize and live in smaller, less expensive homes. Therefore, we expect that seniors may earn smaller tax savings as a percent of their current incomes (due to lower home price appreciation) than non-seniors. The results of our models bear out this expectation. Seniors have lower tax savings as a percent of current income due to a more modest housing consumption preference or because they have higher current income, all else equal. Interestingly, seniors have higher tax benefits as a percent of permanent income (home value), though. To help explain this, we look at Table 4, which shows that seniors were more likely to stay in their homes in 2007. If seniors are less mobile, then they will accumulate more tax savings in their homes, all else equal.

The final source of horizontal inequity that we examine is the length of time that the homeowners have lived in their homes, i.e., the holding period. Not surprisingly, the longer the holding period, the higher the assessment cap tax benefit as a percent of permanent income (Column 1, Table 5). What is somewhat surprising, however, is that the opposite result obtains in the regression run with current income. The results suggest that households holding their homes for a longer time period have a lower tax benefit as a percent of current income. To help explain this, recall that the dependent variable is tax savings divided by current income. There can be no doubt that the absolute tax savings (the numerator) has increased over any holding period due to appreciating housing prices before 2007. Thus, the negative coefficient indicates that because high income owners have longer holding periods, tax savings as a percent of income declines with holding period. We have some evidence of this from the probit model shown in Table 4 . The results show that high income households were less likely to sell in 2007; if this is true in all years, then indeed, high (low) income households have longer (shorter) holding periods.

\section{Conclusions}

Over 20 states have implemented assessment tax limitations and six more have similar measures on the 2010 ballot. In Florida alone, assessment caps grant billions in tax relief to qualifying households. Although voters, policy makers and researchers recognize the importance of assessment cap initiatives, very little is known about who is actually receiving these tax breaks and whether these tax savings are equitably distributed. Evaluations of horizontal and vertical equity provide an important framework for stakeholders to better judge the efficacy and fairness of 
assessment caps on the distribution of property taxes.

Using a selection bias corrected regression that includes a variety of household demographic variables and both current and permanent income measures, we find that assessment cap tax savings make the property tax more progressive. As a percentage of income, low income households receive proportionately larger tax savings from the caps than high income households. This is quite different from previous studies that found that high income households have larger homes that benefit from greater appreciation rates and greater tax savings.

However, when demographic variables that determine socioeconomic status are included in the analysis of the SOH assessment cap, a different, more subtle picture of tax equity emerges. The results suggest that assessment caps increase the property tax burdens of neighborhoods with a high proportion of black households and households with low levels of educational attainment. In terms of their current incomes, Hispanics and households with children receive proportionately higher $\mathrm{SOH}$ tax benefits than other groups. Senior citizens receive proportionately lower tax savings as a percent of their current incomes but proportionately higher benefits relative to their home's value. This runs contrary to the logic that supported passage of the original amendment: senior citizens on a fixed income were suppose to be a key beneficiary of this policy change.

Thus, the equity implications of assessment caps are different depending upon whether one is considering vertical or horizontal equity. From the standpoint of vertical equity, assessment caps improve fairness by making the tax more progressive. However, the horizontal equity implications are more complex. The $\mathrm{SOH}$ tax savings as a proportion of income are different for different demographic and socioeconomic groups, and these differences generally favor the more advantaged groups in society - homeowners who are white and well-educated. Therefore, it is important to consider both horizontal and vertical equity to get the full picture of the incidence of property tax assessment caps.

Table 1: Variable Definitions \& Descriptive Statistics

\begin{tabular}{|c|c|c|c|c|c|}
\hline $\begin{array}{l}\text { Variable } \\
\text { Name }\end{array}$ & Definition & Mean & $\begin{array}{c}\text { Std. } \\
\text { Deviati } \\
\text { on }\end{array}$ & Min & Max \\
\hline $\begin{array}{l}\text { Just Value } \\
\text { (JV1000) }\end{array}$ & $\begin{array}{l}\text { Just/market value of owner-occupied single family homes in } \\
1000 \text { s of dollars per block group }\end{array}$ & 159.843 & 117.839 & 20.532 & 909.158 \\
\hline $\begin{array}{c}\text { Assessed } \\
\text { Value } \\
\text { (AV1000) }\end{array}$ & $\begin{array}{l}\text { Assessed value of owner-occupied single family homes in } 1000 \text { s } \\
\text { of dollars per block group }\end{array}$ & 146.280 & 103.765 & 20.071 & 863.960 \\
\hline $\begin{array}{c}\text { Assessment } \\
\text { Cap } \\
\text { (SOH1000) }\end{array}$ & $\begin{array}{l}\text { Market value shielded from taxation due to Save Our Homes in } \\
1000 \text { s of dollars per block group. }\end{array}$ & 13.565 & 19.422 & 0 & 160.770 \\
\hline $\begin{array}{c}\text { Median } \\
\text { Income } \\
\text { (INC1000) }\end{array}$ & Median income in 1000 s of dollars per block group. & 58.813 & 26.856 & 11.232 & 190.625 \\
\hline WHITE & $\%$ of block group population that is White & 74.77 & 25.83 & 0.08 & 100 \\
\hline $\begin{array}{c}\text { AFRICAN } \\
\text { AMERICAN }\end{array}$ & $\%$ of block group population that is African American & 18.52 & 25.27 & 0 & 99.18 \\
\hline HISPANIC & $\%$ of block group population that is Hispanic & 6.39 & 7.18 & 0 & 37.21 \\
\hline ASIAN & $\%$ of the block group population that is Asian & 2.79 & 4.99 & 0 & 45.79 \\
\hline OTHER & $\%$ of block group population that is Other Race & 3.93 & 4.63 & 0 & 29.34 \\
\hline U18 & $\%$ of block group households with children under 18 & 22.38 & 8.68 & 0 & 57.51 \\
\hline O65 & $\%$ of block group households with head of household age 65 and up. & 14.47 & 9.76 & 0 & 61.30 \\
\hline LESSHS & $\begin{array}{l}\% \text { of block group population that is over } 25 \text { with less than } 12 \text { yrs } \\
\text { of education }\end{array}$ & 11.57 & 9.41 & 0 & 0.7109 \\
\hline $\mathrm{HS}$ & $\%$ of block group population that is over 25 with a high school diploma & 29.02 & 11.81 & 0 & 0.8245 \\
\hline $\begin{array}{l}\text { SOMECOLLE } \\
\text { GE }\end{array}$ & $\begin{array}{l}\% \text { of block group population that is over } 25 \text { with a college } \\
\text { education }\end{array}$ & 32.58 & 9.43 & 6.478 & 59.45 \\
\hline COLLEGE & $\begin{array}{l}\text { \% of block group population that is over } 25 \text { with a bachelor's } \\
\text { degree or higher }\end{array}$ & 26.83 & 17.98 & 0 & 80.16 \\
\hline $\begin{array}{l}\text { SOH\%PERMI } \\
\text { NC }\end{array}$ & $\begin{array}{l}\text { Market value shielded from taxation as a percentage of } \\
\text { permanent income/just value per block group (\%) }\end{array}$ & 7.01 & 6.05 & 0 & 32.96 \\
\hline $\begin{array}{l}\text { SOH\%CURRI } \\
\text { NC }\end{array}$ & $\begin{array}{l}\text { Market value shielded from taxation as a percentage of current } \\
\text { income/median income per block group (\%) }\end{array}$ & 23.52 & 33.04 & 0 & 314.90 \\
\hline
\end{tabular}


Table 2: Suits Index for the 'Save Our Homes' Shielded Market Value by Permanent Income

\begin{tabular}{||c|c|c||}
\hline \begin{tabular}{|} 
Percentile of Block Groups Ranked by \\
Permanent Income (Just/Market Value)
\end{tabular} & $\begin{array}{c}\text { Percent of SOH } \\
\text { Shielded Market Value }\end{array}$ & $\begin{array}{c}\text { Percent of Permanent Income } \\
\text { (Just/Market Value) }\end{array}$ \\
\hline $1^{\text {st }} 10 \%$ & $0.69 \%$ & $0.78 \%$ \\
\hline $2^{\text {nd }} 10 \%$ & $1.49 \%$ & $1.96 \%$ \\
\hline $3^{\text {td }} 10 \%$ & $2.55 \%$ & $3.41 \%$ \\
\hline $4^{\text {th }} 10 \%$ & $3.86 \%$ & $5.14 \%$ \\
\hline $5^{\text {th }} 10 \%$ & $5.50 \%$ & $7.07 \%$ \\
\hline $6^{\text {th }} 10 \%$ & $7.13 \%$ & $9.26 \%$ \\
\hline $7^{\text {th }} 10 \%$ & $10.16 \%$ & $11.88 \%$ \\
\hline $8^{\text {th }} 10 \%$ & $14.68 \%$ & $15.15 \%$ \\
\hline $9^{\text {th }} 10 \%$ & $20.75 \%$ & $19.25 \%$ \\
\hline $10^{\text {th }} 10 \%$ & $33.19 \%$ & $26.10 \%$ \\
\hline \multicolumn{3}{|c|}{} \\
\hline \multicolumn{3}{|c|}{$\begin{array}{c}\text { SUITS INDEX } \\
\text { (slightly progressive) }\end{array}$} \\
\hline \hline
\end{tabular}

Table 3: Suits Index for the 'Save Our Homes' Shielded Market Value by Current Income

\begin{tabular}{||c|c|c||}
\hline \hline $\begin{array}{c}\text { Percentile of Block Groups Ranked } \\
\text { by Current Income (Median Income) }\end{array}$ & $\begin{array}{c}\text { Percent of SOH Shielded } \\
\text { Market Value }\end{array}$ & $\begin{array}{c}\text { Percent of Current Income } \\
\text { (Median Income) }\end{array}$ \\
\hline $1^{\text {st }} 10 \%$ & $1.15 \%$ & $0.88 \%$ \\
\hline $2^{\text {nd }} 10 \%$ & $2.46 \%$ & $2.19 \%$ \\
\hline $3^{\text {td }} 10 \%$ & $4.15 \%$ & $3.77 \%$ \\
\hline $4^{\text {th }} 10 \%$ & $5.79 \%$ & $5.62 \%$ \\
\hline $5^{\text {th }} 10 \%$ & $8.05 \%$ & $7.67 \%$ \\
\hline $6^{\text {th }} 10 \%$ & $10.16 \%$ & $9.96 \%$ \\
\hline $7^{\text {th }} 10 \%$ & $12.58 \%$ & $12.48 \%$ \\
\hline $8^{\text {th }} 10 \%$ & $14.66 \%$ & $15.33 \%$ \\
\hline $9^{\text {th }} 10 \%$ & $18.12 \%$ & $18.80 \%$ \\
\hline $10^{\text {th }} 10 \%$ & $22.88 \%$ & $23.30 \%$ \\
\hline \multicolumn{3}{|c|}{} \\
\hline \multicolumn{3}{|c|}{$\begin{array}{c}\text { SUITS INDEX = } \\
\text { (slightly regressive) }\end{array}$} \\
\hline \hline
\end{tabular}

Table 4: OLS Results of SOH Benefit (Market Value Shielded from Taxation) as a Percentage of Permanent \& Current Income

\begin{tabular}{|c|c|c|c|c|}
\hline & $\begin{array}{c}\text { Market Value Shielded as a } \\
\text { Percentage of Permanent } \\
\text { Income }\end{array}$ & $\begin{array}{l}\text { Market Value Shielded } \\
\text { as a Percentage of } \\
\text { Permanent Income }\end{array}$ & $\begin{array}{c}\text { Market Value Shielded } \\
\text { as a Percentage of } \\
\text { Current Income }\end{array}$ & $\begin{array}{c}\text { Market Value Shielded } \\
\text { as a Percentage of } \\
\text { Current Income }\end{array}$ \\
\hline \multirow[t]{2}{*}{ Just Value (1000s \$) } & $0.0176^{* \pi \times}$ & $\mathrm{n} / \mathrm{a}$ & n/a & $\mathrm{n} / \mathrm{a}$ \\
\hline & $(4.70)$ & & & \\
\hline \multirow[t]{2}{*}{ JV100K to $200 \mathrm{~K}$} & $\mathrm{n} / \mathrm{a}$ & $1.738^{*}$ & $\mathrm{n} / \mathrm{a}$ & $\mathrm{n} / \mathrm{a}$ \\
\hline & & $(2.11)$ & & \\
\hline \multirow[t]{2}{*}{ JV200K to $300 \mathrm{~K}$} & $\mathrm{n} / \mathrm{a}$ & $6.366^{* \pi+2}$ & $\mathrm{n} / \mathrm{a}$ & $\mathrm{n} / \mathrm{a}$ \\
\hline & & $(5.20)$ & & \\
\hline \multirow[t]{2}{*}{ JV300K to $400 \mathrm{~K}$} & $\mathrm{n} / \mathrm{a}$ & $9.917^{*+x}$ & $\mathrm{n} / \mathrm{a}$ & $\mathrm{n} / \mathrm{a}$ \\
\hline & & $(6.07)$ & & \\
\hline \multirow[t]{2}{*}{ JV over $400 \mathrm{~K}$} & $\mathrm{n} / \mathrm{a}$ & $6.670^{* x}$ & $\mathrm{n} / \mathrm{a}$ & $\mathrm{n} / \mathrm{a}$ \\
\hline & & $(3.24)$ & & \\
\hline \multirow[t]{2}{*}{ Income (1000s \$) } & $\mathrm{n} / \mathrm{a}$ & $\mathrm{n} / \mathrm{a}$ & $-0.514^{* * \pi}$ & $\mathrm{n} / \mathrm{a}$ \\
\hline & & & $(-6.05)$ & \\
\hline \multirow[t]{2}{*}{ INC25K to $50 \mathrm{~K}$} & $\mathrm{n} / \mathrm{a}$ & $\mathrm{n} / \mathrm{a}$ & $\mathrm{n} / \mathrm{a}$ & $-20.27^{* 1 *}$ \\
\hline & & & & $(-2.78)$ \\
\hline \multirow[t]{2}{*}{ INC50K to $75 \mathrm{~K}$} & $\mathrm{n} / \mathrm{a}$ & $\mathrm{n} / \mathrm{a}$ & $\mathrm{n} / \mathrm{a}$ & $-33.89^{* * \pi}$ \\
\hline & & & & $(-4.15)$ \\
\hline \multirow[t]{2}{*}{ INC75K to $100 \mathrm{~K}$} & $\mathrm{n} / \mathrm{a}$ & $\mathrm{n} / \mathrm{a}$ & $\mathrm{n} / \mathrm{a}$ & $-46.20^{2 \pi * \pi}$ \\
\hline & & & & $(-4.97)$ \\
\hline
\end{tabular}




\begin{tabular}{|c|c|c|c|c|}
\hline INC over $100 \mathrm{~K}$ & $\mathrm{n} / \mathrm{a}$ & $\mathrm{n} / \mathrm{a}$ & $\mathrm{n} / \mathrm{a}$ & $-54.17^{* t * t}$ \\
\hline & & & & $(-5.22)$ \\
\hline \multirow[t]{2}{*}{ High School } & $-0.155^{\pi x}$ & $-0.134^{*}$ & -0.339 & -0.238 \\
\hline & $(-2.80)$ & $(-2.49)$ & $(-1.17)$ & $(-0.79)$ \\
\hline \multirow[t]{2}{*}{ Some College } & $-0.156^{x+\pi}$ & $-0.148^{x+x}$ & -0.459 & -0.334 \\
\hline & $(-3.51)$ & $(-3.43)$ & $(-1.93)$ & $(-1.31)$ \\
\hline \multirow[t]{2}{*}{ College Degree } & $-0.124^{* \pi}$ & $-0.144^{\text {x*x }}$ & $0.551^{*}$ & $0.560^{\circ}$ \\
\hline & $(-2.96)$ & $(-3.51)$ & $(2.42)$ & $(2.42)$ \\
\hline \multirow[t]{2}{*}{ African American } & 0.00459 & 0.00728 & $-0.171^{*}$ & $-0.208^{*}$ \\
\hline & $(0.31)$ & $(0.47)$ & $(-2.15)$ & $(-2.50)$ \\
\hline \multirow[t]{2}{*}{ Hispanic } & $-0.0992^{*}$ & -0.0850 & -0.358 & -0.317 \\
\hline & $(-2.16)$ & $(-1.90)$ & $(-1.48)$ & $(-1.31)$ \\
\hline \multirow[t]{2}{*}{ Asian } & $-0.140^{*}$ & $-0.135^{*}$ & -0.602 & -0.609 \\
\hline & $(-2.31)$ & $(-2.28)$ & $(-1.89)$ & $(-1.89)$ \\
\hline \multirow[t]{2}{*}{ Other Ethnicity } & 0.0544 & 0.0583 & -0.0816 & -0.0527 \\
\hline & $(0.77)$ & $(0.84)$ & $(-0.22)$ & $(-0.14)$ \\
\hline \multirow[t]{2}{*}{ Kids under 18 in $\mathrm{HH}$} & $-0.180^{\frac{1}{x+2 x}}$ & $-0.150^{\frac{10}{x+3}}$ & $-0.781^{\frac{1}{N+20}}$ & $-0.812^{\text {nkx }}$ \\
\hline & $(-4.30)$ & $(-3.66)$ & $(-3.53)$ & $(-3.66)$ \\
\hline \multirow[t]{2}{*}{65 yrs +} & -0.0628 & -0.0301 & -0.111 & -0.0533 \\
\hline & $(-1.61)$ & $(-0.78)$ & $(-0.55)$ & $(-0.26)$ \\
\hline \multirow[t]{2}{*}{ Constant } & $22.80^{2 \pi x}$ & $21.36^{\sin }$ & $87.38^{n+2 \pi}$ & $80.64^{* \ldots 1}$ \\
\hline & $(5.07)$ & $(4.81)$ & $(3.71)$ & $(3.41)$ \\
\hline Observations & 389 & 389 & 389 & 389 \\
\hline R-squared (Adj) & 0.1699 & 0.2151 & 0.2377 & 0.2334 \\
\hline
\end{tabular}

County dummy variables were also included in the models but they were not statistically significant and have therefore been omitted from this table to simplify the display of results; Standard errors in parentheses; ${ }^{* * *} p<0.01,{ }^{* *} p<0.05,{ }^{*} p<0.1$

\section{References}

Allen, M., 2003. "Measuring vertical property tax inequity in multifamily property markets." Journal of Real Estate Research 25(2), 171-184.

Allen, M. and W. Dare, 2002. "Identifying determinants of horizontal property tax inequity: Evidence form Florida." Journal of Real Estate Research 22(2), 153-165.

Allen, M. and W. Dare, 2009. "Changes in property tax progressivity for Florida Homeowners after the Save Our Homes Amendment.” Journal of Real Estate Research 31(1), 81-93.

Birch, J., M. Sunderman and B. Smith, 2004. "Vertical inequity in property taxation: A neighborhood-based analysis." Journal of Real Estate Finance and Economics (29) (1), 71-88.

Baer, D., 2007. "State and local property tax burdens in 2005." No 2007-09 (Washington D.C. AARP Public Policy Institute, 2007)

Bell, M. and C. Kirschner, 2009. "Alternative measures of effective property tax rates." Public Budgeting and Finance (Summer), 11-136.

Cornia, G. and B. Slade, 2005. "Property taxation of multifamily housing: an empirical analysis of vertical and horizontal equity." Journal of Real Estate Research 27(1), 17-47.

Cornia, G. and B. Slade, 2006. "Horizontal inequity in the property taxation of apartment, industrial, office and retail properties." National Tax Journal 59(1), 33-55.

Dye, R., D. McMillen, D. Merriman, 2006. "Illinois' response to rising residential property values: an assessment growth cap in cook county" National Tax Journal 59(3), 707-716.

Englund, P., 2003. "Taxing residential housing capital." Urban Studies 40(5), 937-952.

Florida Department of Revenue, 2007. "Florida's Property Tax Structure: An Analysis of Save Our Homes and Truth in Millage" Pursuant to Chapter 2006-311, L.O.F., available at http://edr.state.fl.us/Content/specialresearch-projects/property-tax-study/DOR-Property-Tax-Structure-Final-Report-Revised_2.pdf.

Goolsby, W., 1997. "Assessment error in the valuation of owner occupied housing." Journal of Real Estate Research 13(1), 33-45.

Harris, Lee., 2004. "Assessing Discrimination." Journal of Land Use 20(1), 1-60.

Harrison, David, 2010. "Tax Caps Have Big Consequences." available at http://www.stateline.org/live/details/story?contentld=513867

Haverman, Mark and Terri A. Sexton, 2008. "Property Tax Assessment Limits: Lessons from Thirty Years of 
Experience." available at http://www.lincolninst.edu/pubs/dl/1412_986_Property Tax Assessment Limits rev.pdf.

IAAO, 2008. "Assessed Value Cap Overview." Journal of Property Tax Assessment and Administration 7(1), 5767.

McGreal, S. L. Brown, A. Adair, and J.R.Webb, 2007. "Vertical tax equity: An analysis of 7 residential valuation in a major U.K. city." Journal of Housing Research 16 (1), 1-17.

Metcalf, Gilbert, 1994. "The Lifetime Incidence of State and Local Taxes: measuring Changes During the 1980s." Tax Progressivity and Income Inequality, 59-94.

Moore, J. W., 2009. "Property tax equity implications of assessment capping and homestead exemptions for owner occupied single family housing." Journal of Property Tax Assessment and Administration 5(3), 3772.

Musgrave, Richard A., 1959. The Theory of Public Finance. New York: McGraw-Hill.

Phares, Donald, 1980. Who Pays State and Local Taxes. Cambridge: Oelgeschlager, Gunn and Hain.

Plummer, Elizabeth, 2003. "Evidence on the Incidence of Residential Property Taxes Across Households." National Tax Journal 56(1), 739-753.

Sirmans, S. B. Diskin and H. Friday, 1995. "Vertical inequity in the taxation of real property." National Tax Journal 49(1), 71-84.

Smith, B., 2000. "Applying models for vertical inequity in property tax to a non-market value state." Journal of Real Estate Research 19(3), 321-344.

Stiglitz, Joseph, 2000. Economics of the Public Sector Norton and Co. NY, NY.

Stumm, T. and P. Mann, 2004. "Special assessments in Florida cities and counties; dodging Amendment 10." Journal of Public Budgeting, Accounting and Financial Management 16(2), 171-187.

Suits, Daniel, 1977. "Measurement of Tax Progressivity." American Economic Review 76(1), 747-752.

University of Florida Shimberg Center for Affordable Housing, 2007. "Final Report: Analytical Services Relating to Property Taxation," available at http://edr.state.fl.us/property\%20tax\%20study/Report-Assesssment.pdf. 